\title{
Acute Electrical Stimulation of Nucleus Ambiguus Enhances Immune Function in Rats
}

\author{
Ying-Wu Mei, Zhan-Qing Yang, Wei Wang, De-Guang Song, \\ Xu-Ming Deng, Ju-Xiong Liu
}

\begin{abstract}
Background: Up to now, many "immunoactive" brain areas have been identified, such as hypothalamic nuclei, brain reward system; but the nucleus ambiguous (Amb), a nucleus nervi vagis of medulla oblongata, was less well studied in neuroimmunomodulation. Methods: In order to obtain more profound comprehension and more knowledge on Amb, we studied the effect of acute electrical stimulation of Amb on thymus and spleen activity in rat. A stimulator was applied to stimulate the Amb of the anaesthetic rats using the parameter at $100 \mu \mathrm{A} \times 5 \mathrm{~ms} \times 100 \mathrm{~Hz}$ every $1 \mathrm{~s}$ for $1 \mathrm{~min}$. The levels of TGF- $\beta$ and thymosin- $\beta 4 \mathrm{mRNA}$ in thymus, the release of IL-2 and IL-6 at splenocyte in vitro and splenic lymphocyte proliferation were measured at hour $0.5,1,2,3$ following the electrical stimulation. Results: The results showed that concanavalin A (Con A)-induced splenic lymphocyte proliferation and the release of IL-2 and IL- 6 were all significantly enhanced at $0.5,1$, and $2 \mathrm{~h}$ following effective Amb stimulation as compared to in the control group. However, as compared to in the control group, the levels of TGF- $\beta$ and thymosin- $\beta 4$ mRNA in the thymus were both remarkably reduced at $0.5,1$, and $2 \mathrm{~h}$ following effective Amb stimulation. Conclusions: These findings reveal that the Amb participates in the modulation of animal immune functions.
\end{abstract}

RÉSUMÉ: La stimulation électrique aiguë du noyau ambigu stimule la fonction immunitaire chez le rat. Contexte : Plusieurs zones immunoactives du cerveau ont été identifiées jusqu'à maintenant, dont les noyaux hypothalamiques (corps de Luys, noyau sous-thalamique), le système de récompense du cerveau. Cependant, il existe peu d'études sur le rôle du noyau ambigu (Amb), le noyau du nerf vague situé dans le bulbe rachidien, dans la neuro-immunomodulation. Méthodes : Nous avons étudié l'effet de la stimulation électrique aiguë de l'Amb sur l'activité du thymus et de la rate chez le rat afin de mieux connaître et de comprendre le rôle de l'Amb. Un stimulateur a été installé chez des rats anesthésiés pour stimuler l'Amb. Le paramètre utilisé était de $100 \mu \mathrm{A}$ x $5 \mathrm{~ms}$ x $100 \mathrm{~Hz}$ toutes les $1 \mathrm{~s}$ pendant $1 \mathrm{~min}$. Les niveaux de TGF- $\beta$ et d'ARNm de la thymosine $\beta 4$ dans le thymus, la libération d'IL-2 et d'IL-6 par des splénocytes in vitro et la prolifération lymphocytaire splénique ont été mesurés aux temps $0,5 \mathrm{~h}, 1 \mathrm{~h}, 2 \mathrm{~h}$ et $3 \mathrm{~h}$ après la stimulation électrique. Résultats : La prolifération lymphocytaire splénique induite par la concanavaline A (Con A) et la libération d'IL-2 et d'IL-6 étaient significativement augmentées aux temps $0,5 \mathrm{~h}, 1 \mathrm{~h}$ et $2 \mathrm{~h}$ après une stimulation efficace de l'Amb par rapport au groupe témoin. Cependant, les niveaux de TGF- $\beta$ et d'ARNm de la thymosine $\beta$ dans le thymus étaient diminués de façon importante par rapport au groupe témoin aux temps $0,5 \mathrm{~h}, 1 \mathrm{~h}$ et $2 \mathrm{~h}$. Conclusion : Selon ces observation, l'Amb participe à la modulation des fonctions immunitaires chez l'animal.

Can. J. Neurol. Sci. 2008; 35: 441-447

It is well known that there exists bidirectional regulation in the central nervous system (CNS) and immune system. ${ }^{1-3}$ The CNS can have a widespread effect on the immune system following the activation of the hypothalamic-pituitary-adrenal axis $^{4,5}$ and the sympathetic nervous system. ${ }^{3,6,7}$ Thus far, many regions in the brain such as the hypothalamic nuclei, brain reward system, limbic structures, cortex, midbrain periaqueductal gray matter, cerebellum, circumventricular organs, and vagal complex have been identified as "immunoactive" areas. ${ }^{8}$ The nucleus ambiguous (Amb), that is a nucleus of the vagus nerve, is located in the ventrolateral reticulate structure of the medulla oblongata. Thus far, probably owing to traditional ideas regarding this area, study of the Amb was limited to its role in the control of the activity of internal organs and the area was not studied extensively with regard to immunoregulation. In 1981, Dr. Bulloch ${ }^{9}$ discovered a connection between the Amb and thymus, the primary immune

\footnotetext{
From the College of Animal Science and Veterinary Medicine, JiLin University, Changchun, China.

Received November 15, 2007. Final Revisions Submitted April 2, 2008. Correspondence to: Ju-Xiong Liu, College of Animal Science and Veterinary Medicine, JiLin University, 5333 Xi' an Road, Changchun, JiLin province, 130062, P.R.China
} 
organ. Therefore, we speculated that the Amb may have immunoregulatory functions. The present study aimed to investigate this aspect.

The present study was designed to compare the changes in the levels of TGF- $\beta$ and thymosin- $\beta 4$ mRNA in the thymus, the release of IL-2 and IL-6 in the spleen, and splenic lymphocyte proliferation following acute electrical stimulation of the Amb of anesthetized rats. TGF- $\beta$, thymosin- $\beta 4$, IL- 2 , IL- 6 , and splenic lymphocyte proliferation were determined concomitantly in the thymus and spleen of the same individuals.

\section{Materials ANd Methods}

\subsection{Animals}

The experiment was conducted on 42 female Wistar rats (Center of Experimental Animals, Jilin University, China), weighing 240-260 $\mathrm{g}$ were used in this study. Before the experiment, the animals were housed in individual cages under conditions of constant temperature $\left(20^{\circ} \mathrm{C}\right)$ and a 12 hour (h)light/12 h-dark illumination cycle; they had access to food and water ad libitum. Housing and experimental procedures were in accordance with the policy guidelines of the National Institute of Health Guide for the Care and Use of Laboratory Animals (NIH Publications No. 80-23), as revised in 1996.

\subsection{Surgery and electrical stimulation}

The rats were randomly divided into two groups: the electrical stimulation group (36 rats) and the sham control group (six rats); and the rats of electrical stimulation group were randomly divided into four groups again $\left(\mathrm{L}_{0.5 \mathrm{~h}}=10, \mathrm{~L}_{1 \mathrm{~h}}=9\right.$, $\mathrm{L}_{2 \mathrm{~h}}=10, \mathrm{~L}_{3 \mathrm{~h}}=7$ ). Except for the electrical stimulation, the sham control group received the same treatment as the electrical stimulation group; In addition, non-operated rats were acted as normal control. Following the administration of Nembutal (30 $\mathrm{mg} / \mathrm{kg}$, i.p.), the rats were placed in a stereotaxic apparatus (David Kopf 902-A, USA). A stimulating electrode (monopolar stainless steel electrodes, $0.2 \mathrm{~mm}$ in diameter and insulated along the entire length except for the square-cut tip) was aimed at the Amb. The Paxinos and Watson ${ }^{10}$ stereotaxic coordinates were as follows: $12.10 \sim 12.84 \mathrm{~mm}$ posterior to the bregma, 1.98 2.20 $\mathrm{mm}$ lateral to the midline, and $9.22 \sim 9.68 \mathrm{~mm}$ below the skull surface. Using a Nihon Kohden SEN-1703 stimulator, the rats were stimulated at $100 \mu \mathrm{A} \times 5 \mathrm{~ms} \times 100 \mathrm{~Hz}$ every 1 second (s) for 1 minute.

Immunological features were assessed $0.5,1,2$, and $3 \mathrm{~h}$ after the experiment in both the electrical stimulation and control groups.
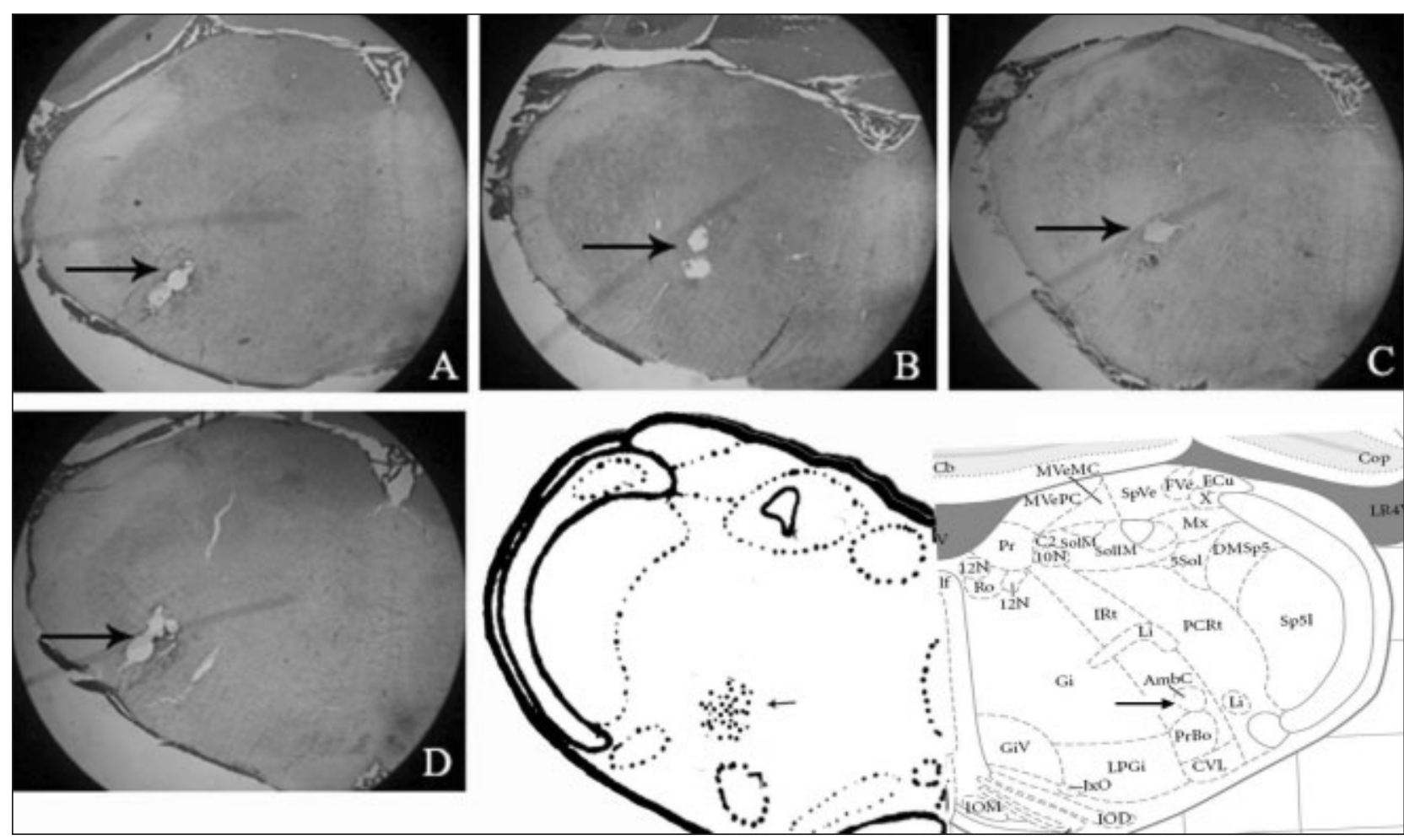

Figure 1: Localization of the tips of the stimulation electrodes, A D is 30um thick section and strained with hematoxylin and eosin. E schematically shows the position of the electrode tip. 


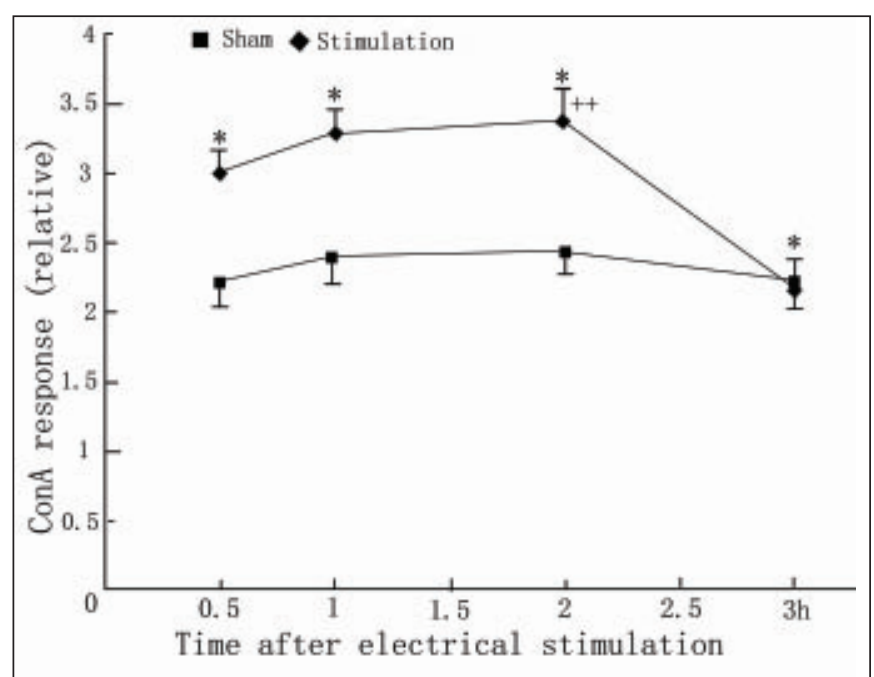

Figure 2: Effect of the electrical stimulation of $A M B$ on Con A-induced splenic lymphocyte proliferation. MTT colorimetric assay was performed on hours 0.5,1,2,3 following the surgery at the electrical stimulus group and the control to evaluate T cell function. Each point is the mean and standard deviation of more six separate experiments. $* P<0.05$, $* * P<$ 0.01 , compared with the control sham-rats; $++P<0.01$, compared with the 0.5-hour rats after electrical stimulation Amb.
2.3 A 3-[4,5-dimethylthiazol-2-yl]-2,5-diphenyl-tetrazolium bromide(MTT) assay for the measurement of Con A-induced proliferation of splenic lymphocytes

A quantitative MTT colorimetric assay was performed as described by Mosmann. ${ }^{11}$ Briefly, the rats of the electrical stimulation and control groups were killed with an overdose of pentobarbital (100 $\mathrm{mg} / \mathrm{kg}$, i.p.) following electrical stimulation at $0.5,1,2$ and $3 \mathrm{~h}$, and their spleens were harvested by celiotomy. Splenic lymphocytes were obtained by gently squeezing the spleen, and they were then washed three times with RPMI 1640 culture medium (Gibco). The erythrocytes were lysed using sterilized distilled water. The lymphocytes were then resuspended in complete culture medium that comprised RPMI 1640 medium, $10 \%$ heat-inactivated fetal calf serum, $2.5 \times 10{ }^{2}$ M 4-(2-hydroxyethyl)-1-piperazineethanesulfonic acid (HEPES) (Sigma), $1 \times 10-^{3} \mathrm{M}$ sodium pyruvate, $5 \times 10-^{5} \mathrm{M}$ bmercaptoethanol, and antibiotics $(100 \mathrm{U} / \mathrm{mL}$ penicillin, 100 $\mathrm{U} / \mathrm{mL}$ streptomycin) at a concentration of $10 \times 10^{6}$ cells $/ \mathrm{ml}$. Cell suspension $(50 \mu \mathrm{L})$ and $50 \mu \mathrm{L}$ Con $\mathrm{A}(10 \mu \mathrm{g} / \mathrm{mL})$ were added in triplicate to 96 -well flat-bottom sterile plates. The plates were incubated in an incubator (ESPEC BNA-311, Japan) at $37^{\circ} \mathrm{C}$ in $5 \%$ carbon dioxide $\left(\mathrm{CO}_{2}\right)$ for $44 \mathrm{~h}$. After incubation, $20 \mu \mathrm{L}$ of 5 $\mathrm{mg} / \mathrm{mL}$ MTT solution was added to each well, and the cells were incubated for an additional $4 \mathrm{~h}$. Thereafter, $100 \mu \mathrm{L}$ dimethyl sulfoxide (DMSO) was added to each well, and the optical density (OD) was read on a Universal Microplate Reader (Elx

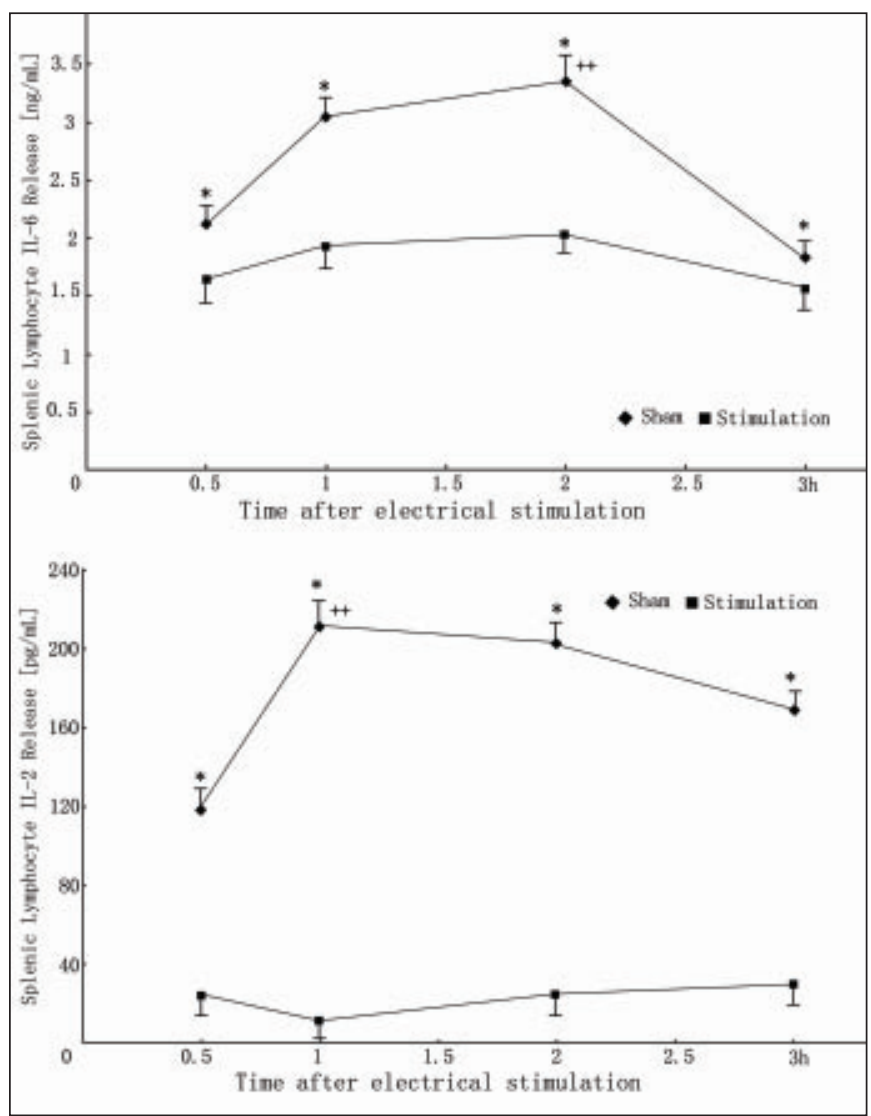

Figure 3: Effects of the different strategies after electrical stimulation and the control in vitro ConA-induced Il-2, IL-6 production. Each point is the mean and standard deviation of more six separate experiments. $* P$ $<0.05, * * P<0.01$, compared with the control sham-rats; $++P<0.01$, compared with the 0.5-hour rats after electrical stimulation Amb.

800, Bio-TEK Instruments, Inc., USA) by using a test wavelength of $490 \mathrm{~nm}$ after $10 \mathrm{~min}$. Proliferation is expressed as the stimulation index (percentage of the unstimulated control), which is the OD of the treated wells/the OD of the unstimulated control wells (cells that received no mitogen).

\subsection{Measurement of IL-2 and IL-6 production in splenic lymphocytes in vitro}

To assess cytokine production, the splenocytes $\left(10 \times 10^{6}\right.$ cells $/ 1 \mathrm{~mL})$ were incubated for $48 \mathrm{~h}\left(37^{\circ} \mathrm{C}, 5 \% \mathrm{CO}_{2}\right)$ in 48 -well tissue culture plates $(0.5 \mathrm{~mL} /$ well $)$ in the presence of Con $\mathrm{A}$ at a concentration of $5 \mu \mathrm{g} / \mathrm{mL}$. After incubation, the supernatants were collected, centrifuged, and stored at $-20^{\circ} \mathrm{C}$ until analysis. Rat enzyme-linked immunosorbent assay (ELISA) mini kits (Boster, WuHan, China) were used for this assay. 


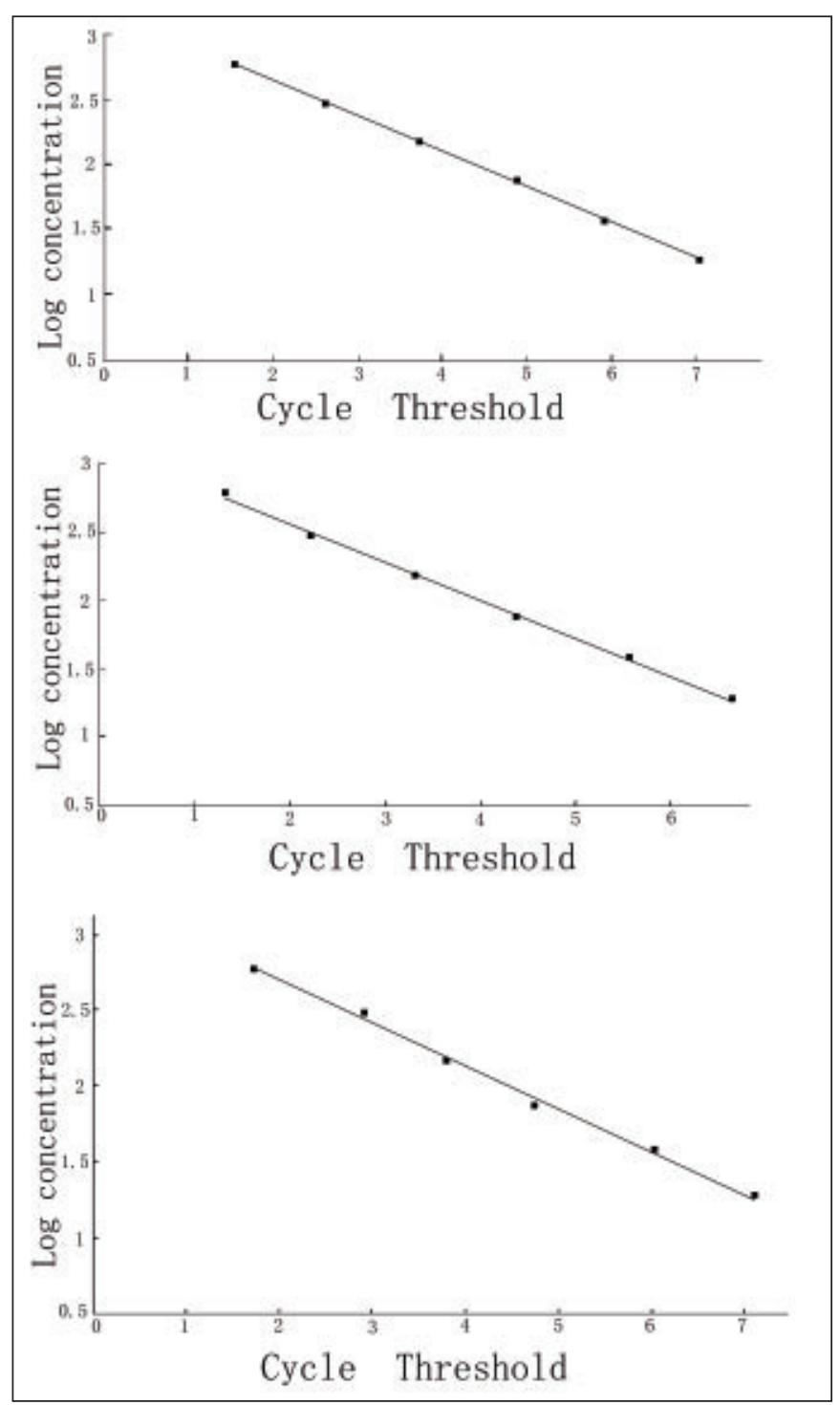

Figure 4: A gradient dilution standard curve was used to calculate the concentration of the thymosin- $\beta 4, T G F-\beta$ and GAPDH mRNA. A: thymosin- $\beta 4, y=-0.2731 x+3.198, R^{2}=0.9998 ; B: T G F-\beta, y=-$ $0.2793 x+3.1154, R^{2}=0.9985 ; C: G A P D H, y=-0.2834 x+3.2683, R^{2}$ $=0.9974$.

\subsection{Real-time polymerase chain reaction (PCR) analysis of thymosin- $\beta 4$ and TGF- $\beta$ mRNA in the thymus}

A realtime PCR assay was performed as described. ${ }^{12,13}$ Rats in the electrical stimulation and control groups were sacrificed at $0.5,1,2$, and $3 \mathrm{~h}$ after receiving the electrical stimulation. Each thymus was rapidly removed and frozen in liquid nitrogen. Total RNA was extracted from the dissected tissue of $30 \mathrm{mg}$ using TRIzol reagent (Gibco BRL, Grand Island, NY) according to the manufacturer's instructions. The integrity and quality of the isolated RNA was examined by quantitating the A260/280 ratio

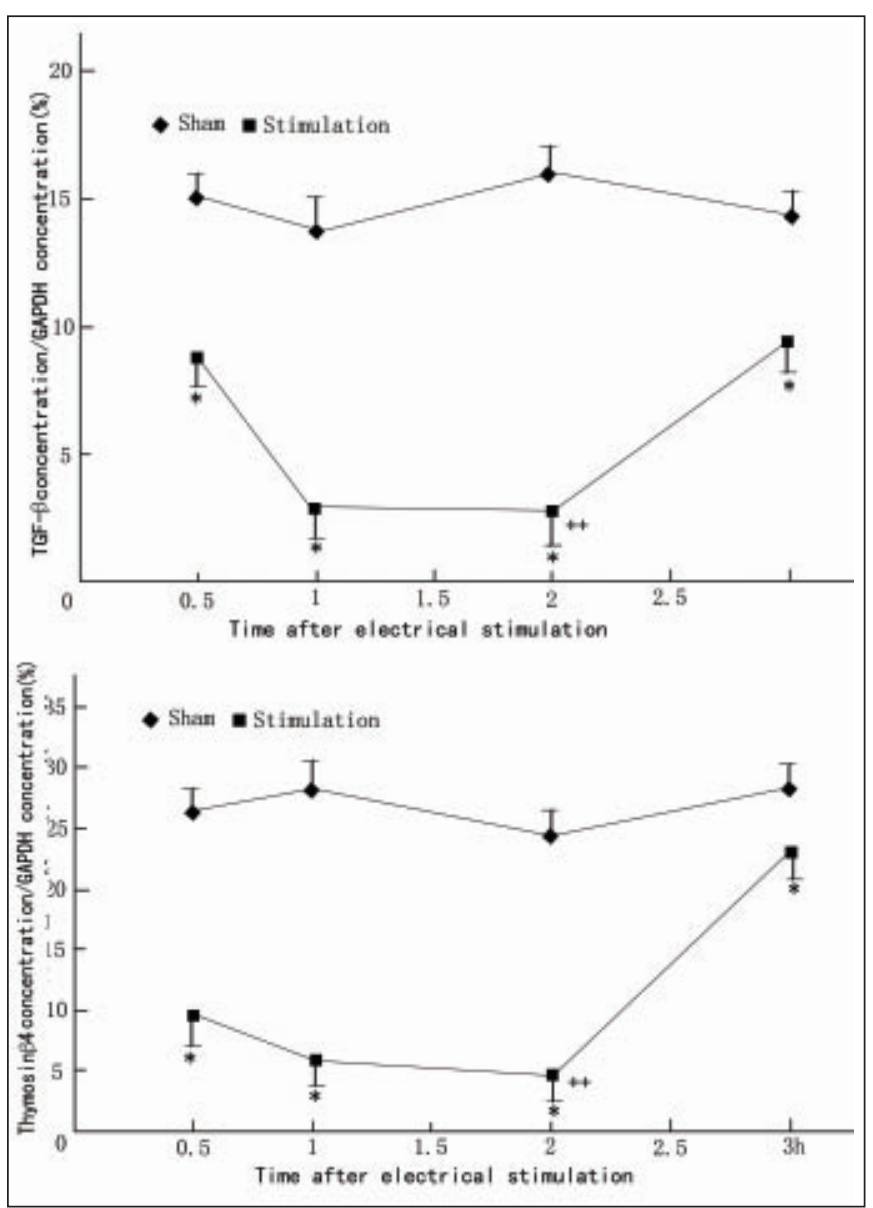

Figure 5: . The levels of thymosin- $\beta 4$ and TGF- $\beta$ mRNA from electrical stimulation and control rats were detected. Total RNA extracted from thymus of rat was reverse-transcribed. cDNA samples were amplified using real-time quantitative $P C R$ and SYBR Green detection as described. The relative amounts of thymosin- $\beta 4$ and TGF- $\beta$ to GAPDH are expressed by ratio in electrical stimulation and control rats $(n \geq 6)$. $* P$ $<0.05, * * P<0.01$, compared with the control sham-rats; $++P<0.01$, compared with the 0.5-hour rats after electrical stimulation Amb.

(BioPhotometer, Eppendorf, Hamburg, Germany) and resolving the RNA on a $1 \%$ agarose gel. The cDNA was prepared from 2.0 $\mu \mathrm{g}$ RNA (OD=1.9 2.0) in the presence of $2.5 \mu \mathrm{M}$ oligo (dT) primer and $200 \mathrm{U}$ Moloney murine leukemia virus reverse transcriptase (M-MLV; Promega, Madison, WI) in a total volume of $20 \mu \mathrm{L}$. The reaction mixture was incubated for $1 \mathrm{~h}$ at $42^{\circ} \mathrm{C}$ and stopped by heating at $90^{\circ} \mathrm{C}$ for $5 \mathrm{~min}$. The real-time PCR primers corresponding to rat TGF- $\beta$, thymosin- $\beta 4$, and glyceraldehyde3 -phosphate dehydrogenase (GAPDH) are listed in the Table. Specific controls were constructed for TGF- $\beta$, thymosin- $\beta 4$ and GAPDH by cloning products of PCR reactions. The PCR products were cloned into a pMD18-T vector (TaKaRa). Twentyfive milliliter LB-broth cultures containing single colonies were grown up overnight, shaking at $200 \mathrm{rpm}$ at $37^{\circ} \mathrm{C}$ and plasmids were subsequently purified using the MiniBEST Plasmid 
Table: Primers for the real time RT-PCR analysis

\begin{tabular}{lcccc}
\hline Gene & Sense (5'-3') & Anti sense (5'-3') & Size (b p) & Gene bank accession no. \\
\hline GAPDH & CTGATGCCTCCATGTTTGTG & GGATGCAGGGATGATGTTCT & 252 & AF106860 \\
TGF- $\beta 1$ & ATGGTGGACCGCAACAAC & CCAAGGTAACGCCAGGAAT & 212 & BC076380 \\
thymosin- $\beta 4$ & CAGCTCCTTCCAGCAACCAT & AAGGCAATGCTCGTGGAATG & 135 & BC058137 \\
\hline
\end{tabular}

Purification Kit Ver. 2.0 (TaKaRa). Plasmid DNAs were solubilised in $150 \mu 1 \mathrm{TE}$ buffer. DNA sequencing confirmed the sequences of the cloned products. Purified plasmid clones were quantified using a BioPhotometer. (Eppendorf, Hamburg, Germany)

Real-time PCR runs were performed in 96-well optical plates in triplicate (each containing $1 \times$ SYBR real-time PCR master mix (ToYoBo), $0.2 \mu 1$ of each primer $(10 \mathrm{mM})$ and $2 \mu 1$ template DNA (either cDNA diluted 1:2 and plasmid DNA dilutions ranging from 1: 2 to 1:128 in a final volume of $25 \mu \mathrm{l}$ ). After preincubation at $95^{\circ} \mathrm{C}$ for $60 \mathrm{~s}$, PCR was performed as follows: 40 cycles of denaturation at $95^{\circ} \mathrm{C}$ for $15 \mathrm{~s}$, annealing at $54^{\circ} \mathrm{C}$ (TGF$\beta$, thymosin- $\beta 4$, and GAPDH), and elongation at $72^{\circ} \mathrm{C}$ for $45 \mathrm{~s}$; dissociation data was automatically captured at the end of the PCR run. Detection was performed using an ABI PRISM 7000 Sequence Detector.

Three standard curves were drawn by plotting the threshold cycle (CT) against the log of the concentration of the plasmids (Figure 4). The CT was defined as the cycle at which a statistically significant increase in the magnitude of the signal generated by the PCR reaction was first detected. The CT was calculated under default settings for the real-time sequence detection software (Applied Biosystems). The equation drawn from the graph was used to calculate the precise concentration of specific cDNA present per microgram of total oligo-dT primed cDNA, tested in the same reaction plate as the standard.

In order to eliminate the error brought by manipulation process, final values were calculated with the specific RNA levels relative to GAPDH RNA.

\subsection{Histological verification}

At $0.5,1,2,3$ hours following the electrical stimulation, the animals were sacrificed, and the localization of the stimulating electrodes was determined. The electrode's tips were marked according to the following procedure. A direct anodal current of $100 \mu \mathrm{A}$ was passed for $20 \mathrm{~s}$ through the electrode of the animals that were previously anesthetized with Nembutal. Subsequently, the brains were removed from the skulls and fixed in $10 \%$ formalin solution. After fixing, the brains were frozen in liquid nitrogen, and sections of 30-nm thickness were cut and stained with hematoxylin and eosin to determine the electrode placements.

\subsection{Statistical analysis}

The data were expressed as mean standard deviation. Statistical analysis was carried out with SPSS 11.5 software. The data were analyzed either by the Student's t-test or two-way analysis of variance. The Student-Newman-Keul's test was also used to compare the data between the groups. Differences were considered statistically significant at $\mathrm{P}<0.05$.

\section{RESULTS}

\subsection{Observations of the electrode placements}

After the experiments were complete, correct placement of the tip of the electrode was verified microscopically in the brain sections stained with hematoxylin and eosin. Figure 1 schematically shows the position of the electrode tip for a stimulated Amb.

\subsection{Results of the measurement of Con A-induced proliferation of splenic lymphocytes}

After the Amb was electrically stimulated, the lymphocytes were prepared from the spleen, and their proliferative response to a T-cell mitogen and Con A was examined. As shown in Figure 2, the MTT assay was performed for the electrical stimulation and control groups at $0.5,1,2$, and $3 \mathrm{~h}$ after the Amb stimulation of the electrical control group; the MTT assay was performed to evaluate lymphocyte proliferation. In the rats of the electrical stimulation group, the stimulation index (SI) values were all significantly increased at $0.5,1$, and $2 \mathrm{~h}$ after the electrical stimulation of the Amb as compared to in the corresponding control rats that received no stimulation. Subsequently, the SI values began to decrease gradually. These results indicate that the acute electrical stimulation of the Amb enhanced the effect of post-stimulation time on the proliferation of splenic $\mathrm{T}$ lymphocytes.

\subsection{Alteration in the production of the cytokines IL-2 and IL- 6 in vitro}

Splenocytes from both groups were stimulated with Con A, and the production of IL- 2 and IL- 6 were determined by rat ELISA mini kits. As shown in Figure 3, as compared to the control group, the production of IL-2 and IL-6 in the electrical stimulation group gradually increased. IL-2 production peaked 1 $\mathrm{h}$ after stimulation, and IL-6 production peaked at $2 \mathrm{~h}$. 
Subsequently, the values began decreasing. These results demonstrated that acute electrical stimulation of the Amb may increase the amounts of IL- 2 and IL- 6 released in splenic lymphocytes in vitro.

\subsection{Alterations in the levels of thymosin- $\beta 4$ and TGF- $\beta$ mRNA in the thymus}

Real time reverse transcriptase (RT)-PCR analysis demonstrated that the expression of thymosin- $\beta 4$ and TGF- $\beta$ mRNA decreased after electrical stimulation of the Amb, as shown in Figure 5. The highest expressions were observed in the control group. Irrespective of thymosin- $\beta 4$ or TGF- $\beta$ mRNA, their expression rapidly decreased and persisted until at least $2 \mathrm{~h}$ after electrical stimulus. Subsequently, at $3 \mathrm{~h}$ after the electrical stimulus, the expressions began to recover.

\section{Discussion}

Studies utilizing CNS lesions or stimulation have suggested that many specific regions of the brain, particularly regions of the hypothalamus and limbic system, may modulate immune activity. However, there are limited reports regarding the effect of Amb-involved immunoregulation thus far. This study evaluates the effects of acute electrical stimulation of the Amb on the expression of TGF- $\beta$ and thymosin- $\beta 4$ mRNA in the thymus, the release of IL-2 and IL-6 in the spleen, and splenic lymphocyte proliferation in anesthetized rats.

In this study, we found that acute electrical stimulation of the Amb caused a dramatic decrease in the levels of thymosin- $\beta 4$ and TGF- $\beta$ mRNA in the thymus and an increase in Con Ainduced lymphocyte proliferation and the production of IL-2 and IL-6. Thymosin- $\beta 4$ was first isolated from calf thymosin fraction 5 ; it is also found in various organs such as the spleen, thymus, liver that exhibit biological activity on the immune system cells. Thymosin- $\beta 4$ has been reported to suppress the mixed lymphocyte proliferative response, ${ }^{14}$ induce the expression of terminal deoxynucleotidyl transferase in $\mathrm{T}$ cells, ${ }^{15}$ inhibit the migration of macrophages in vitro, ${ }^{16}$ and inhibit cytokine production by neutrophils after tumor necrosis factor (TNF)- $\alpha$ stimulation. ${ }^{17}$ TGF- $\beta$, which can be released by thymocyte and thymic epithelial cells, almost inhibits all lymphocyte proliferation, including mitogen- and allogenic antigen-induced T-cell proliferation and Staphylococcus aureus Cowan I (SAC)induced and IL-2 independent B-cell proliferation. Further, TGF$\beta$ can inhibit the functions of cytotoxic T lymphocyte (CTL), natural killer, and lymphokine-activated killer cells and macrophage activity. Further, the immune enhancement activity of IL2 and IL- 6 is now well accepted. Thus, the synchronous decrease in the levels of thymosin- $\beta 4$ and TGF- $\beta$ mRNA along with the synchronous enhancement of Con A-induced lymphocyte proliferation and the production of IL- 2 and IL- 6 indicates that acute electrical stimulation of the Amb can lower the secretion of some immunosuppressive factors and enhance that of others. This may promote immune activity in rats.

The nucleus ambiguus that belongs to a nucleus of the vagus nerve of the medulla oblongata and is an important visceral and somatic motor nucleus that establishes extensive connections with the CNS and peripheral organs. The vagus nerve will be activated by the acute electrical stimulation of the Amb. ${ }^{18-22}$ However, the vagal innervation of the thymus has been debated, ${ }^{9,23-25}$ the splenic nerve comprises approximately $98 \%$ of sympathetic nerve fibers ${ }^{26}$ and there is no direct experimental evidence that supports modulation of thymus and spleen activitives by the vagus nerve. Therefore, we can speculate that there must be other factors underlying this phenomenon. The most convincing is that the hypothalamus plays an important part in this modulation because of its direct or indirect connections with the Amb.27-29 In addition, retrograde tract-tracing techniques combined with immuno-histochemistry were used to found that hypothalamic hcrt-1-containing neurons send collateral axonal projections to cardiovascular sites in the Amb in the rat. ${ }^{30}$

In fact, the effect of neuroimmunomodulation on every region of the hypothalamus has been studied in detail. Destruction of the hypothalamic arcuate nucleus with the neurotoxin monosodium glutamate results in depressed NKCC and proliferation of the large granular lymphocytes (LGL) and in the disappearance of its age-dependent pattern. ${ }^{31}$ Hypophysectomy or adrenalectomy could reverse the effects of the preoptic/ anterior hypothalamus lesions, suggesting that the effects of these lesions on the immune system were mediated via the pituitary hormones or peptides or other neuroendocrine routes. ${ }^{8}$ Mechanical lesion or isolation of the rat hypothalamic paraventricular nucleus (PVN) can selectively reduce the circulating white blood cells and the primary immune response, while it enhances cell-mediated immune function. ${ }^{32,33}$ The authors believe that PVN enhanced cell-mediated immunity functions by altering both the peripheral sympathetic tone and thyroid hormone secretion, and they suggested that the PVN represented an integral part of the neuroendocrine circuit that modulates the immune function of an organism. The lateral and the ventral tegmental area are termed as the "brain reward system." These brain structures are related to positive reinforcement (reward) and have beneficial effects on the immune response, including the antiviral and antitumor cytotoxic activitives of lymphocytes. ${ }^{8}$ Additionally, the hypothalamus could also control the release of humoral immunostimulatory agents such as the adrenocorticotropic hormone, endogenous opioids (particularly b-endorphin), growth hormone, and prolactin, as well as some proinflammatory cytokines. Growth hormone and prolactin are known to stimulate immune responses. ${ }^{34-36}$

In summary, electrical stimulation of the Amb can decrease the secretion of some immunosuppressive factors in the thymus and enhance splenic lymphocyte activity. These findings strongly indicate that the Amb participates in the modulation of animal immune functions.

\section{ACKNOWLEDGEMENTS}

We are grateful to the experimental Animal Center, Jilin University for providing and feeding rats. This work was supported by a grant from the National Natural Science Foundation of China (No.30671535).

\section{REFERENCES}

1. Dantzer R. Innate immunity at the forefront of psychoneuroimmunology. Brain Behav Immun. 2004;18:1-6.

2. Jiang CL, Lu CL, Liu XY. The molecular basis for bidirectional communication between the immune and neuroendocrine systems. Domest Anim Endocrinol. 1998;15:363-9. 
3. Madden KS, Felten DL. Experimental basis for neural-immune interactions. Physiol Rev. 1995;75:77-106.

4. Haddad JJ, Saade NE, Safieh-Garabedian B. Cytokines and neuroimmune-endocrine interactions: a role for the hypothalamicpituitary-adrenal revolving axis. J Neuroimmunol. 2002;133: 1-19.

5. Berczi I, Nagy E. Effect of hypophysectomy on immune function. In: Ader R, Felten D, Cohen N, editors. Psychoneuroimmunology, vol. 2. New York: Academic Press; 1991: p. 337-75.

6. Madden KS. Catecholamines, sympathetic innervation, and immunity. Brain Behav Immun. 2003;17 Suppl 1:S5-10.

7. Hori T, Katafuchi T, Take S, Shimizu N, Niijima A. The autonomic nervous system as a communication channel between the brain and the immune system. Neuroimmunomodulation. 1995;2: 203-15.

8. Wrona D. Neural-immune interactions: an integrative view of the bidirectional relationship between the brain and immune systems. J Neuroimmunol. 2006;172:38-58.

9. Bulloch K, Moore RY. Innervation of the thymus gland by brain stem and spinal cord in mouse and rat. Am J Anat. 1981; 162:157-66.

10. Paxinos G, Watson C. The rat brain in stereotaxic coordinates. 5th ed. San Diego (CA): Academic Press; 2005: p. 173-83.

11. Mosmann T. Rapid colorimetric assay for cellular growth and survival: application to proliferation and cytotoxicity assays. J Immunol Methods. 1983;65:55-63.

12. Whelan JA, Russell NB, Whelan MA. A method for the absolute quantification of cDNA using real-time PCR. J Immunol Methods. 2003;278:261-9.

13. Richards GP, Watson MA, Kingsley DH. A SYBR green, real-time RT-PCR method to detect and quantitate Norwalk virus in stools. J Virol Methods. 2004; 116:63-70.

14. Baxevanis CN, Reclos GJ, Perez S, Kokkinopoulos D, Papamichail M. Immunoregulatory effects of fraction 5 thymus peptides. I. Thymosin alpha 1 enhances while thymosin beta 4 suppresses the human autologous and allogeneic mixed lymphocyte reaction. Immunopharmacology. 1987;13:133-41.

15. Low TL, Hu SK, Goldstein AL. Complete amino acid sequence of bovine thymosin beta 4 : a thymic hormone that induces terminal deoxynucleotidyl transferase activity in thymocyte populations. Proc Natl Acad Sci USA. 1981;78:1162-6.

16. Thurman G, Low T, Rossio J, Goldstein A. Specific and nonspecific macrophage migration inhibition. In: Goldstein AL, Chiligos MA, editors. Lymphokines and thymic hormones: Their potential utilization in cancer therapeutics. New York: NY; Raven. 1981: p. 145.

17. Sosne G, Wheater M, Qiu P, Christopherson P. Thymosin Beta 4 inhibits neutrophil production of cytokines after TNF-Alpha stimulation. Invest Ophthalmol Vis Sci. 2007;48:3649.

18. S Nosaka KYaST. Vagal cardiac preganglionic neurons: distribution, cell types, and reflex discharges. Am J Physiol Regul Integr Comp Physiol. 1982;243:R92-8.

19. Ciriello J, Calaresu FR. Medullary origin of vagal preganglionic axons to the heart of the cat. J Auton Nerv Syst. 1982;5:9-22

20. Spyer MK. Neural organization and control of the baroreceptor reflex. Rev Physiol Biochem Pharmacol. 1981;88:23-124.
21. Ciriello J, Calaresu FR. Distribution of vagal cardioinhibitory neurons in the medulla of the cat. Am J Physiol. 1980;238: R57-64.

22. S Nosaka TY, K Yasunaga. Localization of vagal cardioinhibitory preganglionic neurons within rat brainstem. J Comp Neurol. 1979;186:79-92.

23. Trotter RN, Stornetta RL, Guyenet PG, Roberts MR. Transneuronal mapping of the CNS network controlling sympathetic outflow to the rat thymus. Auton Neurosci. 2007;131:9-20.

24. Niijima A, Hori T, Katafuchi T, Ichijo T. The effect of interleukin-1 beta on the efferent activity of the vagus nerve to the thymus. J Auton Nerv Syst. 1995;54:137-44.

25. Nance DM, Hopkins DA, Bieger D. Re-investigation of the innervation of the thymus gland in mice and rats. Brain Behav Immun. 1987;1:134-47.

26. Klein RL, Wilson SP, Dzielak DJ, Yang WH, Viveros OH. Opioid peptides and noradrenaline co-exist in large dense-cored vesicles from sympathetic nerve. Neuroscience. 1982;7:2255-61.

27. Sakai K, Yoshimoto Y, Luppi PH, Fort P, el Mansari M, Salvert D, et al. Lower brainstem afferents to the cat posterior hypothalamus: a double-labeling study. Brain Res Bull. 1990;24: 437-55.

28. Volz HP, Rehbein G, Triepel J, Knuepfer MM, Stumpf H, Stock G. Afferent connections of the nucleus centralis amygdalae. A horseradish peroxidase study and literature survey. Anat Embryol (Berl). 1990;181:177-94.

29. Wild JM, Arends JJ, Zeigler HP. Projections of the parabrachial nucleus in the pigeon (Columba livia). J Comp Neurol. 1990; 293:499-523.

30. Ciriello J, McMurray JC, Babic T, de Oliveira CV. Collateral axonal projections from hypothalamic hypocretin neurons to cardiovascular sites in nucleus ambiguus and nucleus tractus solitarius. Brain Res. 2003;991:133-41.

31. Belluardo N, Mudo G, Bindoni M. Effects of early destruction of the mouse arcuate nucleus by monosodium glutamate on agedependent natural killer activity. Brain Res. 1990;534:225-33.

32. Hefco V, Olariu A, Hefco A, Nabeshima T. The modulator role of the hypothalamic paraventricular nucleus on immune responsiveness. Brain Behav Immun. 2004;18:158-65.

33. Hefco VP, Olariu A, Neacsu I, Isaicul A. The ways through which the hypothalamic paraventricular nucleus $(\mathrm{PVH})$ and the medial hypothalamus affect the organism's defence function. Rom J Physiol. 1993;30:87-91.

34. Esquifino AI, Arce A, Alvarez MP, Chacon F, Brown-Borg H, Bartke A. Differential effects of light/dark recombinant human prolactin administration on the submaxillary lymph nodes and spleen activity of adult male mice. Neuroimmunomodulation. 2004:11:119-26.

35. Dorshkind K, Horseman ND. The roles of prolactin, growth hormone, insulin-like growth factor-I, and thyroid hormones in lymphocyte development and function: insights from genetic models of hormone and hormone receptor deficiency. Endocr Rev. 2000;21:292-312.

36. Kelley KW. Growth hormone, lymphocytes and macrophages. Biochem Pharmacol. 1989;38:705-13. 